Revista de

Contabilidade e

Organizações
http://dx.doi.org/10.11606\%2Frco.v7i17.56666
Journal of

Accounting and

Organizations

\title{
Environmental information disclosure: a proposed indicator based on experts' perceptions
}

\author{
Ramon K. B. Bachmannª Leandro M. Carneiro ${ }^{a}$ Márcia M. S. B. Espejo
}

${ }^{a}$ Universidade Federal do Paraná, PPG-Mestrado em Contabilidade.

\section{Article Info}

Article history

Received: 23 May 2012

Accepted: 5 January 2013

Key words

Attributes

Environmental Disclosure Disclosure

Indicator

Sustainability

\begin{abstract}
This paper is aimed at listing environmental attributes, according to the degree of importance of disclosure, to compose a truly Brazilian indicator that assesses the quality of environmental information disclosure. "Environmental accounting/sustainability" experts and environmental disclosure attributes were selected, based on Brazilian and international studies. Through Delphi rounds, the experts outlined the list of the most relevant attributes to compose the indicator. The Environmental Disclosure Indicator - EDI consists of ten attributes than combine practicality and representativeness of the quality of environmental information disclosure. The results revealed a high degree of importance and, therefore, a greater weight of qualitative attributes, such as "Environmental Impacts of Products and Processes" and "Information about Residues". The study contributes by revealing "what" should be disclosed prioritarily, that is, which are the essential environmental attributes. It contributes to verify whether the amount of environmental information companies have disclosed have necessarily meant disclosure quality. As it provides an instrument to quantify the quality of environmental disclosure, the study permits further research about the association between this disclosure and other company aspects, such as performance and corporate governance.
\end{abstract}

Copyright (C) 2013 FEA-RP/USP. All rights reserved.

\section{INTRODUCTION}

Organizations are increasingly adopting environmental accountability practices, in response to pressure from society in general as well as from public policies, with a view to seeking better human conditions and social equality. The theme - sustainability, environmental issues, socioenvironmental responsibility - addresses a polysemic study area with a wide range of meanings for the concepts used (Moretti; Campanario, 2009). According to the authors, bibliometrics research on Corporate Social Accountability reveals that this thematic approach has been limited to a bulwark of some few prolific researchers, symbolizing a yet elite area.

According to Ribeiro (2006), companies need to demonstrate their commitment to the preservation, maintenance and recovery of the natural resources used or

Corresponding author: Tel (55 41) 33604417

E-mail addresses: ramon_bach@yahoo.com.br (R.K.B.Bachmann),

le.m.carneiro@gmail.com.br (L.M.Carneiro),marciabortolocci@ufpr.br (M.M.S.B.Espejo) impaired in the production process to their users, disclosing information on the entity's interaction with the environment, that is, disseminating all spending on environmental investments, costs and expenses.

A study by the consulting company KPMG identified that, among the 250 largest companies around the world, $79 \%$ publish a sustainability report. In principle, this data can be understood as a good sign of environmental disclosure. Authors affirm, however, that information quality has not increased (Cintra, 2011).

According to Machado, Nascimento and Murcia (2009), although social and environmental accounting research is hardly representative in the pool of accounting research, social and/or environmental disclosure is a core theme, in which most studies use documentary research to reach the proposed objectives. Measuring sustainability disclosure, however, remains a relatively unexplored field (Corina; Taplin, 2011).

Freitag (2011) defined the current state of the art of Brazilian research on environmental disclosure, based on studies published on the occasion of the 
Encounters of the National Association of Graduate and Research Programs in Administration - EnANPAD, as in a "primitive stage" so far. In addition, Nossa (2002) affirms that the debate about environmental information disclosure continues focusing on "what" and "how" environmental disclosure should be done and about whether standardization is actually possible or even acceptable.

Thus, the apparent contradiction between environmental information quantity and quality, besides the lack of studies to support environmental information disclosure quality measurement, imply the need to create an instrument to assess the environmental disclosure companies provide through their reports, with a view to appointing "what" should be disclosed. Therefore, this study is aimed at answering the following question: what is the composition of an environmental information disclosure quality indicator according to experts in the area? The aim of the research is to list the main environmental information disclosure attributes based on experts' opinion in the area, leading to the creation of the Environmental Disclosure Indicator - EDI.

The study by Cintra (2011) reveals that the significant increase in the socio-environmental disclosure volume in recent years supports the focus on academic accounting disclosure studies. Costa and Marion (2007) also affirm that environmental accounting is aimed at measuring and disclosure environmental information in specific reports or in the actual financial statements. They emphasize the need to create methods to measure and disclose environmental impacts, allowing more companies to follow that structure. The environmental accounting field, according to Elkington (2012), is relatively embryonic; the literature produced is increasing though. According to Nossa (2002), companies are not only expected to operate in an environmentally sustainable manner, but also to publicly demonstrate information on their actions and procedures.

\section{SUSTAINABILITY AND ENVIRONMENTAL DISCLOSURE}

Sustainability has turned into a recurrent research theme in different areas (Alves, 2008), also as a target of "fashion trends" for the adjective. The term itself started being used with such different meanings that its origin has even been forgotten (Veiga, 2005). The "sustainability" concept coined by the United Nations Sustainable Development Concept through the Brundtland report (named after the chairwoman of the World Commission on Environment and Development, Gro Harlem Brundtland), was widely disseminates and refers to "met the needs of the present generation without compromising the ability of future generations to satisfy their own needs" (Gray; Milne, 2002, p.01).

For the corporate sector, the sustainability concept represents a new approach to doing business, which promotes social inclusion (with respect for cultural diversity and the interests of all publics directly or indirectly involved in the business). It reduces - or optimizes - the use of natural resources and the impact on the environment, preserving the integrity of the planet for future generations, without ignoring the economicfinancial profitability of the business. In combination with best practices in corporate governance, corporate sustainability creates value for stockholders and enhances the probability of the business' going-concern in the long term, at the same time as it contributes to maintain social wellbeing (BM\&FBovespa, 2011).

One of the notions of this concept for organizations can be visualized based on three perspectives, which are: the economic, the social and the environmental, the socalled Triple Bottom Line. Elkington (2012) comprehends the notion of understanding sustainable development for beyond a sole end result, in this case the economic. Therefore, organizations should also acknowledge social and environmental performance results.

The economic dimension consists in the efficient allocation of production resources. The social dimension refers to companies' contributions to human development, in the form of measures related to collaborators' remuneration, safe environment, non-exploration of child labor and slave work, among others. Finally, the environmental (or ecologic) dimension covers aspects related to the ecosystem. It comprises natural resources, the quality of the air, water and soil, forests and ecology (BM\&FBovespa, 2011).

In this context, according to Schaltegger, Benett and Burritt (2006), companies are key factors for economic, environmental and social wellbeing. Corporate sustainability is therefore necessary in the long term, as well as the sustainable development of the economy and society as a whole.

Ribeiro (2006) describes that companies are receiving pressure from different segments to improve and enhance their productive processes, with a view to reducing aggressions against the environment. Some businessmen already acknowledge that environmental protection and preservation can provide for a better income flow. The author affirms that important changes have occurred in corporate behavior in recent decades, making annual reports rich in information, including qualitative data.

Involvement in the theme is also possible for different reasons, such as the strategic course, business opportunity, business ethics, pressure from stakeholders and interest (Moretti; Campanario, 2009). Environmental information disclosure is aimed at clarifying the corporate actions developed to minimize the environmental impacts operational performance has caused (Almeida et al., 2010). Despite the strong appeal of corporate marketing, the information provided has stimulated competitors' corporate behavior towards the development of similar or better actions, resulting in benefits for society in general (Ribeiro, 2006).

Schaltegger, Benett and Burritt (2006) argue that it is not clear yet when a company can be considered as having achieved the state of "being sustainable". Sustainable corporate development can be understood as the set of 
processes put in practice to reduce corporations' negative impacts and enhance their positive impacts, with a view to achieving a sustainable economy, environment and society. The authors affirm that information about the impacts of sustainability on corporate performance is aimed at helping managers to consider resource maintenance in their planning, execution and control decisions regarding the company's daily activities. Thus, accounting and the elaboration of sustainability reports can serve to collect, analyze and communicate corporate environmental information, turning them into crucial tools to improve mere economic and financial management into a conscious and sustainable management model.

According to Nossa (2002), the contents about what should be included in environmental accounting or sustainability reports have aroused discussions among researchers as well as in institutional organizations in the area. That author considers that the credibility of sustainability reports remains very low, mostly due to difficulties to comply with qualitative informational characteristics.

If not communicated, however, this accounting information may not exert any influence whatsoever and, consequently, become incapable of contributing to the company's sustainable development. Hence, information needs to be reported that reliably represents the organization's position towards environmental issues, revealing possible progress achieved in that sense (Nossa, 2002).

As opposed to the lack of information quality, the number of environmental information (especially through the internet) has considerably increased. In most cases, information is descriptive and limited to mentioning that "the company invested in environmental preservation" (Ribeiro, 2006).

According to Cintra (2011), a considerable number of companies have published socio-environmental information in the last two decades. Part of this increase has been influenced by different environmental report awards and ranking, established by environmental and social entities (Nossa, 2002), like the Corporate Sustainability Index - CSI of the São Paulo Stock Exchange (BM\&FBovespa). The aim of the CSI is to reflect the return of a portfolio consisting of company stock with renowned commitment to social responsibility and corporate sustainability (Murcia et al., 2008a).

Different environmental guidelines, especially about disclosure and sustainability reports, are under development (Nossa, 2002), including the Global Reporting Initiative- GRI, the Global Environmental Management Initiative - GEMI, the Agenda 21, the Eco-Management and Audit Scheme - EMAS, the Intergovernmental Working Group of Experts on International Standards of Accounting and ReportingISAR, among others.

Corina and Taplin (2011) address environmental disclosure from two perspectives, disclosure by abundance and by range of events. The first is generally measured by applying content analysis to the disclosure volume in the reports, measured based on the quantity of disclosure (such as phrases, key words). The second, then, refers to the analysis of the occurrence of disclosure, known as the disclosure index. This indicator expresses the number of items in a checklist or a disclosure index, thus measuring the range of information disclosure. It does not consider the degree of importance of one information type over the other though, that is, it attributes the same weight to all environmental information types disclosed. Each of these aspects captures one perspective on organizational disclosure.

As a third perspective, in addition to the study by Corina and Taplin (2011), the different environmental themes disclosed could be examined, distinguishing them by degree of importance and, therefore, attributing distinct weights to each environmental attribute that is to be disclosed through corporate reports.

\section{METHODOLOGICAL PROCEDURES}

The aim of exploratory-descriptive research, mainly quantitative, is to contribute to the creation of an environmental information disclosure quality indicator. To reach the proposed objectives, as a technical procedure, Delphi rounds with environmental accounting experts were used. The Delphi technique is intended to structure communication in an expert group, in search of a specific result, with a view to reaching a consensus about the research subject (Sáfadi, 2001).

In summary, it is a method to structure group communication processes, allowing a group of individuals to deal with a complex problem. The technique implies the constitution of an expert group in a given knowledge area, who issue their opinions and should remain anonymous (Lyra, 2008).

The method has four basic characteristics: (i) interaction among experts, including the exchange of information and opinions; (ii) maintenance of anonymity for experts and their answers; (iii) feedback that permits the review of individual opinions in view of other experts' opinions; and, (iv) processing and analysis of answers according to a statistical pattern (Lyra, 2008).

Thus, to apply the Delphi rounds, the following had to be defined: (1) the group of environmental experts invited to participate in the research; and (2) environmental information disclosure items, as potential EDI components.

The expert selection involved two phases. First, through a list of Stricto Sensu (Master's and Ph.D.) Graduate Programs in Accounting, recognized by the Coordination for the Improvement of Higher Education Personnel - CAPES, all faculty members involved were listed by consulting each higher education institution's website. Then, each researcher's Lattes curriculum was verified, selecting those researchers in whose curriculum the introductory test revealed involvement with sustainability, environmental accountability and related themes. To confirm each researcher's involvement, each 
curriculum was analyzed in terms of scientific production compatible with the research theme. This screening resulted in a list of 36 experts.

The second expert selection phase involved checking researchers affiliated with Research Groups of the Brazilian Scientific and Technological Development
Council - CNPq related to accounting and sustainability/ environmental accountability. Thus, 17 research groups were identified. Twelve of these are clearly related to the research theme and five gave signs of this relation through the key words, as displayed in Table 1.

Table 1. CNPq Research Groups related to the research theme

CNPq Research Groups clearly related to the proposed theme

1) GDS - Socio-environmental Development Management;

2) Study Group on Accounting and the Environment (NECMA/USP);

3) Socio-environmental Studies;

4) Environmental Accounting and Social Reports Group;

5) Global Environmental Governance and Clean Development Mechanism;

6) Local Development, Sustainability and Accounting;

7) Study Group on Accounting and the Environment - NEMAC;

8) Sustainability and Governance Observatory;

9) SIADES - Environmental Information System for Sustainable Development;

10) Corporate Socio-environmental Accountability;

11) Advanced Studies for Sustainability;

12) GPS - Research Group on Sustainability and Innovation.

CNPq Research Groups that indicate relations through the key words

1) FECAP Observatory of Accounting Research and Education;

Key words: Environmental accounting or industrial costs, Environmental education and Cost accounting.

2) NPGO -Research Group on Governance in Organizations;

Key words: Environmental accounting, Social accounting, Governance.

3) Management, Control and Accounting-Financial Measurement;

Key words: Environmental accounting, Sustainable development, Environmental management, Environmental performance indicators, Sustainability.

4) GEFIC - Study Group on Finance and Accounting;

Key words: Sustainable development, Environmental management.

5) Study Group on Organizational Innovations.

Key words: Environmental management, Social management, New productive arrangements, Sustainability.

Source: elaborated by the authors.

Next, after a new analysis of each participating researcher's Lattes curriculum, experts were selected who demonstrated involvement with the study theme or had produced scientific publications on the theme.

Thus, in this second phase, 31 experts were added (after discounting those included in the first phase), resulting in the final list of 67 experts to be invited to participate in the research.

The second measure needed was the definition of items for possible inclusion in the Environmental Disclosure Indicator. The selection of these disclosure attributes, which the experts assessed during the Delphi rounds, was based on a literature review of the main publications on "environmental information disclosure", found in the CAPES Portal. The selected studies were screened for environmental information disclosure attributes as described above.

Table 2 shows the references that contributed attributes to the formulation of the initial instrument used in the Delphi rounds.
Table 2. References that contributed attributes

\begin{tabular}{l|l}
\hline Authors & Year \\
\hline 1) Deegan & 2002 \\
\hline 2) Patten & 2002 \\
\hline 3) Dalmácio and Paulo & 2004 \\
\hline 4) Costa and Marion & 2007 \\
\hline 5) Rover, Murcia, Borba and Vicente & 2008 \\
\hline 6) Almeida, Rêgo, Pessoa, Santiago and Melo & 2010 \\
\hline 7) Antunes, Milani Filho and Condini & 2010 \\
\hline 8) Global Reporting Initiative - GRI & 2010 \\
\hline 9) São Paulo Stock Exchange - BM\&FBOVESPA & 2011 \\
\hline
\end{tabular}

Source: elaborated by the authors.

Hence, the initial instrument for application during the Delphi rounds was elaborated based on 49 environmental attributes companies should disclosed, found in the nine references displayed in Box 2. In total, 49 attributes were selected, after excluding those items that were repeated among the references reviewed or found in other research sources without new items. In 
the Table 3, the 49 environmental information disclosure attributes used in the first Delphi round are displayed.

Table 3. Attributes selected for disclosure

\begin{tabular}{|c|c|c|c|}
\hline $\begin{array}{l}\text { 1. Declaration of corporate } \\
\text { environmental policies. }\end{array}$ & $\begin{array}{l}\text { 14. Conditioning process } \\
\text { (packing). }\end{array}$ & $\begin{array}{l}\text { 26. Investment in funds } \\
\text { (environmental portfolios). }\end{array}$ & $\begin{array}{l}\text { 40. Environmental protection } \\
\text { works. }\end{array}$ \\
\hline $\begin{array}{l}\text { 2. Declaration of current and } \\
\text { future environmental policies. }\end{array}$ & $\begin{array}{l}\text { 15. Recycled products. } \\
\text { 16. Development of ecological }\end{array}$ & $\begin{array}{l}\text { 27. Investment in environmental } \\
\text { machinery and equipment. }\end{array}$ & $\begin{array}{l}\text { 41. Environmental education } \\
\text { programs (internally and/or } \\
\text { community). }\end{array}$ \\
\hline $\begin{array}{l}\text { 3. Setting of environmental } \\
\text { targets and objectives. }\end{array}$ & $\begin{array}{l}\text { products. } \\
\text { 17. Product innovations related }\end{array}$ & $\begin{array}{l}\text { 28. Environmental costs and/or } \\
\text { expenses. }\end{array}$ & $\begin{array}{l}\text { 42. Environmental studies / } \\
\text { research. }\end{array}$ \\
\hline $\begin{array}{l}\text { 4. Information about } \\
\text { environmental regulations and } \\
\text { entities. }\end{array}$ & $\begin{array}{l}\text { to reduced environmental } \\
\text { degradation. }\end{array}$ & $\begin{array}{l}\text { 29. Accumulated environmental } \\
\text { amortization, depreciations, } \\
\text { exhaustion. }\end{array}$ & $\begin{array}{l}\text { 43. Environmental study and } \\
\text { research incentives. }\end{array}$ \\
\hline $\begin{array}{l}\text { 5. Mention of company's } \\
\text { environmental compliance. }\end{array}$ & 19. Soil degradation. & 30. Environmental provisions. & $\begin{array}{l}\text { 44. Clean Development } \\
\text { Mechanism (CDM) Projects. }\end{array}$ \\
\hline $\begin{array}{l}\text { 6. Partnership with environmental } \\
\text { organizations. }\end{array}$ & 20. Efficient water use/reuse. & $\begin{array}{l}\text { 31. Environmental } \\
\text { contingencies. }\end{array}$ & 45. Carbon credit. \\
\hline $\begin{array}{l}\text { 7. Award and participations in } \\
\text { environmental indices. }\end{array}$ & $\begin{array}{l}\text { 21. Environmental accidents. } \\
\text { 22. Environmental recovery }\end{array}$ & $\begin{array}{l}\text { 32. Environmental damage } \\
\text { lawsuits (indemnifications and } \\
\text { fines). }\end{array}$ & $\begin{array}{l}\text { 46. Greenhouse Gas Emission } \\
\text { (GGE). }\end{array}$ \\
\hline 8. ISO $9.000 \mathrm{and} /$ or 14.000 . & $\begin{array}{l}\text { practices. } \\
\text { 23. Preservation and/or }\end{array}$ & $\begin{array}{l}\text { 33. Environmental contingency } \\
\text { reserve. }\end{array}$ & $\begin{array}{l}\text { 47. Emission Reduction } \\
\text { Certificates (ERC). }\end{array}$ \\
\hline 9. Environmental audit. & $\begin{array}{l}\text { more efficient energy use in } \\
\text { operations. }\end{array}$ & 34. Environmental protection & $\begin{array}{l}\text { 48. Environmental forestation } \\
\text { and/or reforestation. }\end{array}$ \\
\hline $\begin{array}{l}\text { 10. Environmental management } \\
\text { program (long-term). }\end{array}$ & $\begin{array}{l}\text { 24.Use of wasted materials in } \\
\text { energy production. }\end{array}$ & $\begin{array}{l}\text { reserve. } \\
\text { 35. Environmental accounting }\end{array}$ & 49. Preservation of biodiversity. \\
\hline $\begin{array}{l}\text { 11. Environmental management } \\
\text { projects (short-term). }\end{array}$ & $\begin{array}{l}\text { 25. Development of new } \\
\text { energy sources. }\end{array}$ & $\begin{array}{l}\text { practices. } \\
\text { 36. Environmental insurance. }\end{array}$ & \\
\hline $\begin{array}{l}\text { 12. Environmental impacts } \\
\text { of products and processes } \\
\text { (atmospheric, water, sound, } \\
\text { visual pollution). }\end{array}$ & $\begin{array}{l}\text { 26. Investment in funds } \\
\text { (environmental portfolios). }\end{array}$ & $\begin{array}{l}\text { 37. Tangible and intangible } \\
\text { environmental assets. }\end{array}$ & \\
\hline $\begin{array}{l}\text { 13. Information on residues and } \\
\text { waste. }\end{array}$ & $\begin{array}{l}\text { 27. Investment in } \\
\text { environmental machinery and } \\
\text { equipment. }\end{array}$ & $\begin{array}{l}\text { 38. Fields and mines. } \\
\text { 39. Dredging works. }\end{array}$ & \\
\hline
\end{tabular}

Source: elaborated by the authors.

After obtaining the potential attributes to compose the EDI, as well as the experts invited to participate in the Delphi rounds, an instrument was elaborated to assess the attributes. The first instrument question asked the participant to respond, using a Likert scale, whether (s)he had intensely studied the theme sustainability/ environmental accounting in the last five years. The aim of this question was to guarantee the invitee's actual expert status. The answers of those who marked "I disagree" or "I completely disagree" were dropped.

Next, the experts were asked to score each of the attributes according to a lesser or higher degree of importance of disclosure in company reports, using a scale from 0 to 10 . Thus, the idea was to discover the most important attributes to compose the EDI. The researchers consider the more important attributes in the composition of the EDI make the instrument reflect the quality of disclosure. In other words, companies that disclose more important environmental attributes in their reports have a higher-quality environmental disclosure, resulting in a higher EDI.

After forwarding the instrument and compiling the results found in this first Delphi round, 30 attributes were selected, which showed mean scores above the general mean (mean score of 49 attributes), so as to forward the new instrument in the second Delphi round. In this second round, the experts were asked to score ten out of the 30 attributes between 1 and 10, with 1 indicating the lowest importance in terms of disclosure and 10 the highest importance, without repeated scores or attributes scored more than once. The aim of this procedure was to filter those attributes the experts considered most important in terms of environmental disclosure, as well as to reduce the number of attributes to compose the EDI, turning it into a more practical and applicable indicator.

With a view to interaction among the experts' answers, making them reflect on the scores attributed in the first round and complying with the first basic characteristic (information exchange) of the Delphi technique (Lyra, 2008), in the second round, the mean score of each attribute obtained in the first round was informed. Among the 30 attributes the experts had considered most important for disclosure in the first Delphi round, 26 were scored, leading to the exclusion of the four attributes that were not scored. 
Figure 1. General methodological scheme of EDI construction

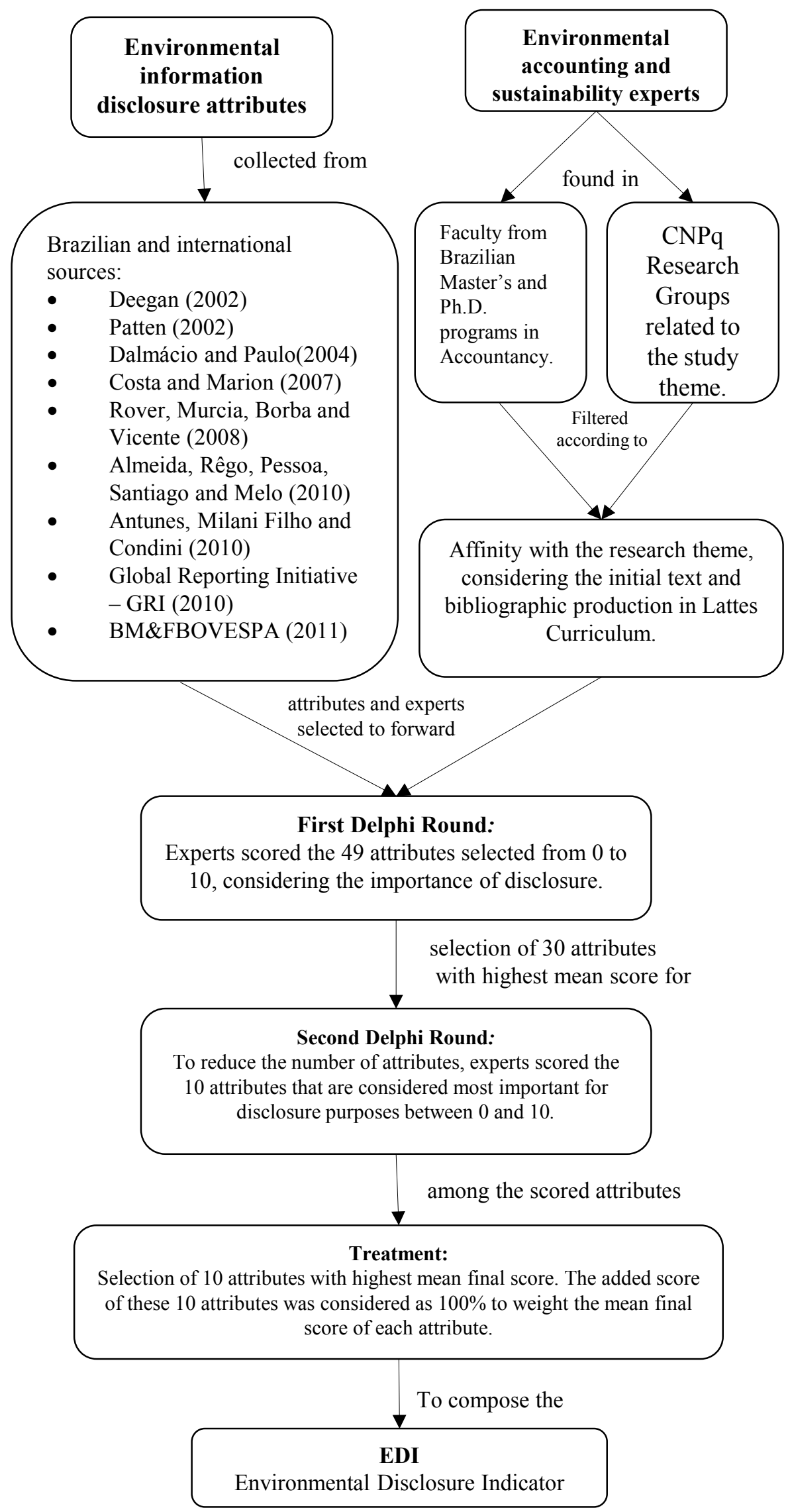


After this 26-attribute screening, special attention was paid to the analysis of the relation between the indicator's representativeness (relevant percentage of total importance of disclosure expressed by the experts at the end of the second Delphi round) versus practicality (reasonable amount of attributes to be checked in the corporate reports).

If all experts selected the same attributes among the 30 and scored them between 1 and 10, the EDI would consist of ten attributes with $100 \%$ of environmental disclosure importance (ideal situation).

If the experts did not select the same attributes for the sake of disclosure, the representativeness percentage of the ten attributes with the highest score among the 26 items scores would have to be analyzed. Thus, the researchers looked for a set of attributes that would be represent the importance of disclosure, but would also be practical for the sake of scientific research.

Finally, by adding up the experts' scores for each attribute, the attribute with the highest score was granted the highest weight in the EDI and that with the tenth highest total score the lowest weight.

Weights were obtained proportionately by the attribute's total score in the relation to the sum of the total scores for the ten attributes included in the indicator. Figure 1 displays the methodological scheme used to build the EDI, as detailed here.

In the following section, the main empirical results of the two suggested Delphi rounds are presented, as well as the treatment applied to the environmental disclosure attributes that were obtained through the bibliographic review and were filtered by the experts.

\section{RESULTS AND DISCUSSION}

The aim of the Delphi rounds was to identify the main environmental information attributes for organizational disclosure, in the attempt to reach a consensus among the experts, based on a list of attributes found in studies published about the theme.

In the first round, out of 67 questionnaires that were forwarded, 14 were answered. Only 12 of these were considered valid, as two experts marked "I disagree" or "I completely disagree" on the question about their recent involvement in environmental research.

The general mean score for the 49 attributes was 8.43, showing the importance of the set of items. To apply the second Delphi rounds, the attributes whose score was equal to or higher than the general average (30 attributes) were maintained. The results of the items that scored equal to or higher than the general average are displayed in Table 4.

The instrument used for the second round consisted of the 30 items resulting from the previous round and was again forwarded to the experts. Nine answers were received, only one of which was considered invalid due to the expert's lack of involvement in the research area.
After adding up the attribute scores, 26 items resulted. The experts did not score the attributes "Environmental management projects (short term)", "Conditioning process (packing)", "Soil degradation" and "Greenhouse Gas Emission (GHG)".

Table 4. Attributes selected after first Delphi round

\begin{tabular}{|c|c|}
\hline Attributes & Mean \\
\hline $\begin{array}{l}\text { Environmental impacts of products and processes } \\
\text { (atmospheric, water, sound, visual pollution) }\end{array}$ & 9.50 \\
\hline Information on residues and waste & 9.50 \\
\hline Environmental protection works & 9.33 \\
\hline $\begin{array}{l}\text { Preservation and/or more efficient energy use in } \\
\text { operations }\end{array}$ & 9.33 \\
\hline Efficient water use/reuse & 9.25 \\
\hline Environmental accounting practices & 9.17 \\
\hline Environmental management program (long term) & 9.17 \\
\hline Conditioning process (packing) & 9.00 \\
\hline Environmental protection reserve & 9.00 \\
\hline Establishment of environmental targets and objectives & 9.00 \\
\hline Development of new energy sources & 9.00 \\
\hline Environmental costs and/or expenses & 8.83 \\
\hline Tangible and intangible environmental assets & 8.75 \\
\hline $\begin{array}{l}\text { Environmental damage lawsuits (indemnifications and } \\
\text { fines) }\end{array}$ & 8.75 \\
\hline Recycled products & 8.67 \\
\hline Environmental study and research incentives & 8.67 \\
\hline $\begin{array}{l}\text { Accumulated environmental amortization, depreciation, } \\
\text { exhaustion }\end{array}$ & 8.67 \\
\hline Greenhouse gas emission (GGE) & 8.67 \\
\hline Environmental audit & 8.67 \\
\hline Environmental insurance & 8.67 \\
\hline $\begin{array}{l}\text { Product innovations related to environmental } \\
\text { degradation reduction }\end{array}$ & 8.58 \\
\hline Emission Reduction Certificates (ERC) & 8.50 \\
\hline $\begin{array}{l}\text { Environmental education programs (internally and/or } \\
\text { community) }\end{array}$ & 8.50 \\
\hline Environmental provisions & 8.50 \\
\hline Declaration of corporate environmental policies & 8.50 \\
\hline Use of waste materials in energy production & 8.50 \\
\hline Environmental studies / research & 8.43 \\
\hline Environmental management projects (short term) & 8.43 \\
\hline Reserve for environmental contingencies & 8.43 \\
\hline Soil degradation & 8.43 \\
\hline
\end{tabular}

In total, the experts could distribute 440 points among the 26 attributes, 290 of which were concentrated among the ten first items, representing about $65 \%$ of the total importance the experts attributed. The next step was to determine whether these ten attributes, corresponding to $65 \%$ of the importance of disclosure, respect the best possible relation between practicality and representativeness. Therefore, Graph 1 was elaborated, which relates the accumulated percentage of disclosure importance with the number of attributes included in the indicator.

Graph 1. Representativeness versus Practicality 


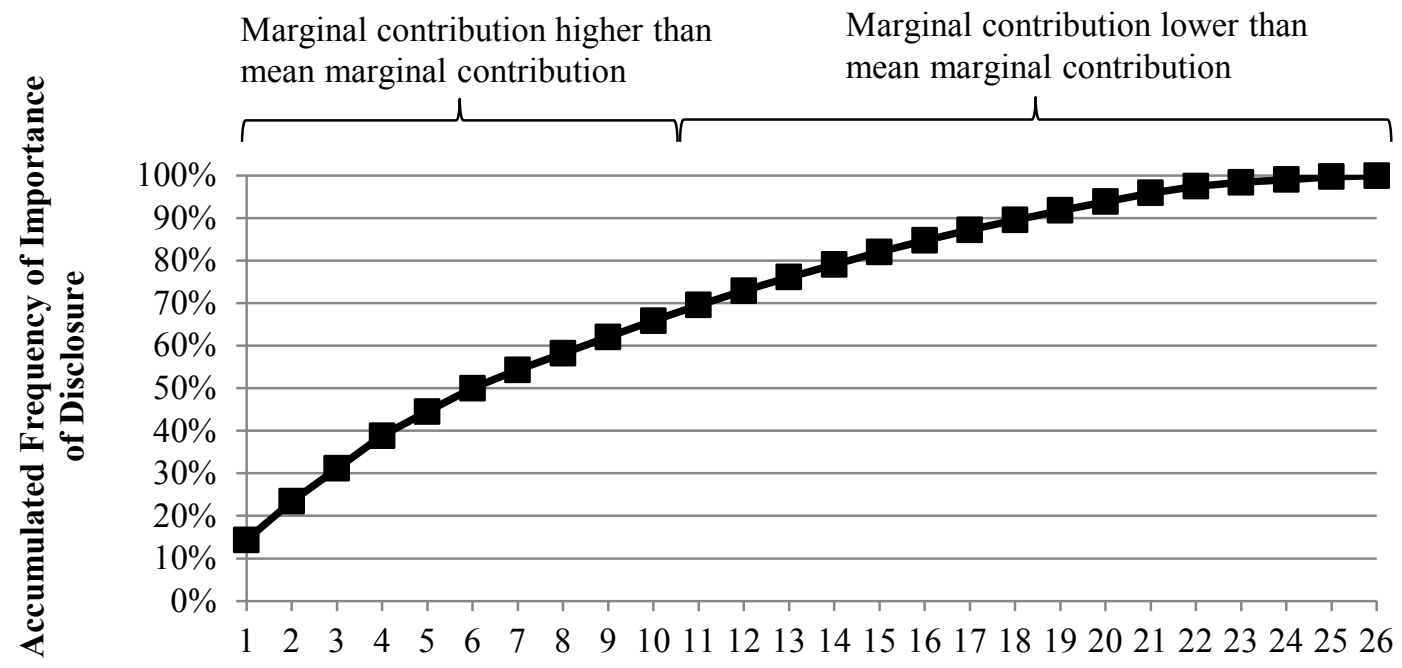

Number of Attributes

This representation reveals that, for each attribute included in the indicator, the marginal contribution of representativeness drops. An indicator that considers only one attribute, for example, carries $14.32 \%$ of representativeness. When adding another attribute to the indicator, the additional importance is $9.09 \%$, instead of the same $14.32 \%$, representing a two-attribute EDI, but with $23.41 \%$ of representativeness.

The mean marginal contribution of the 26 attributes was calculated, corresponding to approximately $3.43 \%$. Hence, as the tenth attribute contributes with about
$3.64 \%$ of disclosure importance when related to the ninth attribute, it should be included in the EDI. The eleventh attribute, however, contributes with a mere $3.41 \%$ of disclosure importance in relation to the tenth, making its inclusion into the indicator disadvantageous.

Therefore, the optimal model in terms of representativeness versus practicality should consist of the ten indicators with the highest weights, corresponding to about $65 \%$ of representativeness of the importance of disclosure. Table 5 presents the ten items selected for inclusion in the EDI.

Table 5. Selected attributes for the Environmental Disclosure Indicator (EDI)

\begin{tabular}{l|c|c|c}
\hline \multicolumn{1}{c|}{ Composition of Environmental Disclosure Indicator } & Added score & $\begin{array}{c}\text { EDI } \\
\text { composition }\end{array}$ & $\begin{array}{c}\text { Score variation } \\
\text { coefficient }\end{array}$ \\
\hline $\begin{array}{l}\text { 1- Environmental impacts of products and processes (atmospheric, } \\
\text { water, sound, visual pollution) }\end{array}$ & 63 & $22 \%$ & 0.329 \\
\hline 2- Information about residues and waste & 40 & $14 \%$ & 0.177 \\
\hline 3 - Establishment of environmental targets and objectives & 34 & $11 \%$ & 0.263 \\
\hline 4 - Environmental management program (long-term) & 34 & $11 \%$ & 0.280 \\
\hline $5-$ Declaration of corporate environmental policies & 25 & $9 \%$ & 0.658 \\
\hline 6 - Efficient water use/reuse & 24 & $8 \%$ & 0.497 \\
\hline $7-$ Environmental audit & 19 & $7 \%$ & 0.434 \\
\hline $8-$ Environmental accounting practices & 17 & $6 \%$ & 0.367 \\
\hline $9-$ Environmental protection reserve & 17 & $6 \%$ & 0.620 \\
\hline $10-$ Environmental costs and/or expenses & 17 & $6 \%$ & 0.753 \\
\hline Total & 290 & $100 \%$ & \\
\hline
\end{tabular}

Table 5 shows the total scores for each attribute and the final composition of the EDI. In addition, the variation coefficients of the scores the eight experts who participated in the second Delphi round attributed to each item are presented. This measure, calculated by dividing the standard deviation of the scores by each attribute's mean score, expresses the degree of consensus among the experts. The lower the variation coefficient, the smaller the score range, that is, the greater the consensus among the expert opinions. This measure was used as a tiebreaker to rank attributes with the same score.

The attributes obtained after the two Delphi rounds were fit into the conceptual environmental information structure proposed by Murcia et al. (2008a), reaching four main categories: (a) Impact of Products and Processes; (b) Environmental Policies; (c) Environmental Management Systems; and, (d) Environmental Financial Information.

The attributes related to the category (a) Impact of 
Products and Processes obtained the highest scores, ranking first and second, respectively. The following fit into this category: "(1) Environmental Impacts of Products and Processes", which includes atmospheric, water, sound and visual pollution; "(2) Information about Residues and Waste”, besides“(6) Efficient Water Use/ Reuse".

According to CONAMA Resolution n. 01 (1986), which sets criteria within the National Policy for the Environment, environmental impact is considered as any change in the physical, chemical and biological properties of the environment, caused by any form of matter or energy resulting from human activities that direct or indirectly affect: (i) the health, safety and wellbeing of the population; (ii) social and economic activities; (iii) biota; (iv) esthetic and sanitary conditions of the environment; and, (v) quality of environmental resources.

In the same category, the item "(6) Efficient Water Use / Reuse", corresponding to $8 \%$ of the total, relates to the idea of eco-efficiency. This concept involves the supply of goods and services at competitive price that attend to human needs, offering quality of life and progressively reducing ecological impacts and the intensity of resources. This supply should be compatible with the planet's productive capacity (Elkington, 2012).

The concept suggests a significant link between resource efficiency (leading to productivity and profitability) and environmental accountability. Hence, eco-efficiency refers to the more efficient use of materials and energy, with a view to lowering economic costs and environmental impacts (Elkington, 2012). One may say that eco-efficiency means combining economic and environmental performance, minimizing environmental impacts, using raw material and energy more rationally, reducing accident risks and improving the relation between the organization and the stakeholders.

According to Elkington (2012), these environmental impact-related items entail an increasing need to measure them in terms of new measuring standards, such as the number of public complaints, impacts of the product lifecycle, use of energy, materials and water, garbage production, among others.

In the category (b) Environmental Policies, the items "(3) Establishment of Environmental Targets and Objectives" and "(5) Declaration of Corporate Environmental Policies" correspond to organizations' expressions about an actual policy statement, declarations about formal intentions and general declarations about what "the company will, the company does" with regard to the environment (Gray; Kouhy; Lavers, 1995, p.98).

“(5) Declaration of Corporate Environmental Policies" is considered as an organization's intentions and general principles related to its environmental performance, formally approved by top management and within a corporate range, that is, they should be valid across all organizational units. The environmental policy should address at least, besides legal compliance, commitments to the prevention of potential and actual environmental impacts of an organization's activities, products and services, to the continuous improvement of environmental performance and to the sustainable use of natural resources (BM\&FBovespa, 2011).

The category (c) Environmental Management Systems includes the attributes "(4) Long-Term Environmental Management Programs" and "(7) Environmental Audit". Despite the tie with the attribute ranked third, the item "(4) Long-Term Environmental Management Programs" was ranked fourth as it revealed a higher variation coefficient, which means less consensus among the experts' scores for this attribute. These programs tend to be formal, with specific resources, timetable, specific targets and responsibilities defined by the Administration (BM\&FBovespa, 2011).

As regards "(7) Environmental Audit”, the aim of environmental audits is to assess the state of a company's management systems and its progress towards a range of indicators and objectives. According to Elkington (2012), such audits should focus on organizations' environmental impact. Most of them, however, only focus on management systems and not on actual environmental effects.

Items related to the category (d) Environmental Financial Information, such as "(8) Accounting Practices for Environmental Items”, “(9) Reserve for Environmental Protection" and "(10) Environmental Costs and/or Expenses" received the same score, leading to a tie among the final three places and a ranking based on the scores' variation coefficient, using the same procedure applied to the third and fourth attributes.

Regarding environmental costs and expenses (item 8), the UN (1998) emphasizes that these comprise spending to manage the impacts of corporate activities, besides other expenses for the same goal. Ribeiro (2006) clarifies that environmental costs and expenses include expenses to: (i) prevent, reduce or repair damage to the environment, resulting from operational activities, or needed to preserve resources that are renewable or not; and (ii) eliminate or avoid sludge, preserve or improve air quality, reduce noise, remove contamination from buildings, research on the development of products, raw material or production processes.

Regarding item “(9) Reserve for Environmental Protection", which represents an element in the organization's liabilities (Almeida et al., 2010), it corresponds to potential environmental obligations deriving from past events whose results will be confirmed only in case of the occurrence, or non occurrence, of one or more uncertain future events beyond the company's control (Nossa, 2002).

Item "(10) Environmental Accounting Practices" corresponds to the company's environmental guidelines in the treatment of environmental assets, liabilities, expenses and losses. Accounting practices in general correspond to the set of standards and interpretations issued by different organizations in the country. These practices are normally based on fundamental accounting principles, on Brazilian accounting standards, relevant legislation and specific accounting aspects for different market segments. Although some countries issue 
voluntary and others compulsory standards, according to Deegan (2002), most environmental reporting practices remain voluntary.

Besides the attributes the experts selected as extremely important to compose the index, that is, those attributes with the highest total score obtained through the application of the Delphi technique, some categories had little or no repercussion in the scientific community. It should be highlighted, for example, that Clean Development Mechanism (CDM), Carbon Credits and Greenhouse Gas Emission (GHG) projects, regulated through the Kyoto Protocol, were not validated as very important for disclosure.

The results appointed support the perspective of Murcia et al. (2008b) about the incipient treatment and relatively recent nature of these attributes, although they were included in the research. On the other hand, these products represent environmental product markets as emission quota and "pollution rights" (Veiga, 2005), which hardly contributes to the sustainability discussion.

Information about awards and participations in environmental indices - like the Corporate Sustainability Index coordinated by BM\&FBovespa - and certifications like ISO 9.000 and/or ISO 14.000 were not considered important to disclose either.

Although the selected participants are accounting experts, most of the selected attributes figure on a more qualitative list. According to the experts, traditional accounting and environmental items, such as "Environmental Assets", "Accumulated Environmental Amortization, Depreciation and Depletion" are not very important for the sake of environmental disclosure, and therefore were not included in the EDI.

\section{FINAL CONSIDERATIONS}

The aim in this paper was to list the most important environmental information disclosure attributes according to environmental accounting/sustainability expert opinions, with a view to the elaboration of an Environmental Disclosure Indicator (EDI). Thus, the study attempted to contribute to the debate about organizations' sustainability perspective.

To achieve this aim, the Delphi technique was applied among the experts selected from the teaching staff of M.Sc. and Ph.D. programs in Accounting and $\mathrm{CNPq}$ research groups related to the theme, according to their affinity with the research theme, observed through the content analysis of the Lattes curricula.

To define the attributes for evaluation, bibliographic analyses were undertaken in Brazilian and international sources on the theme, resulting in a list of 49 items. To identify the main environmental information attributes for organizational disclosure, based on the greatest possible consensus among the experts, two Delphi rounds were held. In both, great disparity was verified among the respondents, indicating the complexity of the issue in the different experts' opinions. In the first round, when the experts were asked to score the 49 items on a scale from 0 to 10 , the general mean score was 8.43 .

In the second round, the 30 items with the scores above the general average obtained in the first round were present. The experts were asked to choose the ten most important items for environmental information disclosure purposes. To compose the EDI, the ten first items from the final ranking were used. The selected items correspond to about $65 \%$ of all scores the experts attributed to all environmental disclosure items at the end of the second Delphi round.

In the analysis of the Indicator's composition, the importance attributed to items in the category Impacts of Products and Processes was verified, showing the highest participation in the ranking $(44 \%$ of total disclosure importance). Second came the attributes in the category Environmental Policies (20\%), which were relevant by disclosing statements about targets and objectives and about environmental policies. Finally, the categories Environmental Management Systems and Environmental Financial Information corresponded to $18 \%$ each in the EDI.

According to Veiga (2005), although a consensus on environmental sustainability indicators remains far-off, the issue is to understand that these play a fundamental role in the surveillance and pressure relations governments and international organizations need to exert over companies. Similarly, disclosure indicators play an important role in the transparency of organizational relations with the environment.

This study contributes by revealing "what" should be disclosed in terms of environmental information, in accordance with the study by Nossa (2002). By listing informational attributes according to the level of importance, this research can support the creation of standardized environmental responsibility reports, which governmental entities can start requiring in the future.

This study also contributes to verify whether the amount of environmental information companies have disclosed has necessarily meant a better disclosure quality. In addition, by providing an instrument to quantify the quality of environmental disclosure, the study permits future research about the link between disclosure and other company aspects, including performance, corporate governance, among others.

For the sake of future research, environmental disclosure could be measured in a range of companies to validate the EDI. It should also be highlighted that the research was based on the perceptions of academic experts who are Graduate Accounting Program teaching staff members.

Therefore, the confrontation between theoretical experts' results and results from expert opinions in other knowledge areas is proposed, as well as in the business context, including administrators, market analysts and sustainability managers. 


\section{REFERENCES}

Almeida, F. P., Rêgo, T. de F., Pessoa, L.G.de S. B., Santiago, J. S. \& Melo, J. F. M. (2010). Evidenciação de itens ambientais nas indústrias siderúrgicas registradas na Bovespa. In: Congresso Brasileiro de Custos. XVII.. Anais... Belo Horizonte: CBC.

Alves, Denis Lima. (2008). Sustentabilidade: estado da arte e um estudo de evento sobre o Índice de Sustentabilidade Empresarial. Dissertação (Mestrado em Administração) - Universidade Federal de Uberlândia, Uberlândia.

Antunes, M. T. P., Milani Filho, M. A. \& Condini, P. H. (2010) Indicadores de sustentabilidade de instituições financeiras: uma análise evolutiva da evidenciação voluntária baseada no relatório GRI. In: Congresso Brasileiro de Custos. XVII. Anais... Belo Horizonte: CBC

BM\&FBovespa (2011). Bolsa de Valores, Mercadorias e Futuros. Índice de Sustentabilidade Empresarial - ISE. Recuperado em: 08/09/2011, de http://www. bmfbovespa.com.br/Indices/download/ISE_Questionario2011.pdf. .

Brasil (1986). Conselho Nacional do Meio Ambiente. Resolução CONAMA n. 001, de 23 de janeiro de 1986. Dispõe sobre a Política Nacional do Meio Ambiente. Brasília.

Cintra, Y. C. (2011). A integração da sustentabilidade às práticas de controle gerencial das empresas no Brasil. Tese Doutorado em Controladoria e Contabilidade. Universidade de São Paulo, São Paulo.

Corina, J \& Taplin, R. (2011). The measurement of sustainability disclosure: abundance versus occurrence. Accounting Forum. 35, 19-31.

Costa, R. S. da \& Marion, J. C. (2007). A uniformidade na evidenciação das informações ambientais. Revista Contabilidade e Finanças. 18(43), 20-33.

Dalmácio, F. Z. \& Paulo, F. (2004). F. M. A Evidenciação Contábil: publicação de aspectos sócio-ambientais e econômico-financeiros nas Demonstrações Contábeis. BBR Brazilian Business Review, Vitória. 1(2), 74-90.

Deegan, C. (2002). The legitimising effect of social and environmental disclosures: a theoretical foundation. Accounting, Auditing \&Accountability Journal. 15(3), 282-311.

Elkingtin, J. (2012). Sustentabilidade: canibais com garfo e faca. M.Books do Brasil, São Paulo.

Freitag, V. da C. Estado da arte da pesquisa em evidenciações ambientais. Revista ADMpg Gestão Estratégica, v.4, n.1, 2011.

Gray, R., Kouhy, R. \& Lavers, S. (1995). Methodologi- cal themes: constructing a research database of social and environmental reporting by UK companies. Accounting, Auditing \&Accountability Journal. 8(2),78-101.

\& Milne, M. J. (2002). Sustainability reporting: who's kidding whom? Working Paper, Chartered Accountants Journal of New Zealand. 81(6), 66-70.

Guimarães, R. P. \& Feichas, S. A. Q. (2009, julho/dezembro). Desafios na construção de indicadores de sustentabilidade. Ambiente \& Sociedade. Campinas. $12(2), 307-323$.

Lyra, R. L. W. C. de. (2008). Análise hierárquica dos indicadores contábeis sob a óptica do desempenho empresarial. $171 \mathrm{f}$. Tese Doutorado em Controladoria e Contabilidade. Universidade de São Paulo, São Paulo.

Machado, M. R., Nascimento, A. R. \& Murcia, F. D. R. (2009). Análise crítica-epistemológica da produção científica em contabilidade social e ambiental no Brasil. In: Congresso Brasileiro de Custos. XVII.. Anais... São Paulo. FEA/USP.

Moretti, S. L. do A. \& Campanario, M. de A. (2009, junho). A produção intelectual brasileira em Responsabilidade Social Empresarial - RSE sob a ótica da bibliometria. Revista de Administração Contemporânea. Curitiba. 13, 68-86.

Murcia, F. D. R., Rover, S., Lima, I., Fávero, L. P. L. \& Lima, G. A. S. F. de. (2008a, janeiro/dezembro). 'Disclosure Verde' nas demonstrações contábeis: características da informação ambiental e possíveis explicações para a divulgação voluntária. Revista UnB Contábil. Brasília. 11(1-2),260-278.

, Rover, S., Souza, F. C. de \& Borba, J. A. (2008b, maio/agosto). Aspectos metodológicos da pesquisa acerca da divulgação de informações ambientais: proposta de uma estrutura para análise do disclosure ambiental das empresas brasileiras. Revista de Gestão Social e Ambiental (RGSA). 2(2), 88-104.

Nossa, V. (2002). Disclosure ambiental: uma análise do conteúdo dos relatórios ambientais de empresas do setor de papel e celulose em nivel internacional. Tese Doutorado em Controladoria e Contabilidade. Universidade de São Paulo, São Paulo.

Organizações das Nações Unidas (ONU). (1998). Comission on Investment, Technology and Related Financial Matters of Working Group of Experts on International Standards of Accounting and Reporting, Environmental financial accounting and reporting at the corporate level. Recuperado em: 27 de abril de 2012, de http://www.unctad.org/em/docs/ c2isar.pdf.

Patten, D. M. (2002, novembro). The relation between environmental performance and environmental disclosure: a research note. Accounting, Organizations and Society. 27(8), 763-773. 
Ribeiro, M. de S. (2006). Contabilidade ambiental. São

Paulo: Saraiva.

Rover, S., Murcia, F. D. R., Borba, J. A. \& Vicente, E. F.

R. (2008, maio/agosto). Divulgação de informações ambientais nas demonstrações contábeis: um estudo exploratório sobre o disclosure das empresas brasileiras pertencentes a setores de alto impacto ambiental. Revista de Contabilidade e Organizações. 3(2), 53-72.

Sáfadi, C. M. Q. (2001). Delphi: um estudo sobre sua aceitação. In: Semead, 5, 2001, São Paulo. Anais... São Paulo: FEA/USP. Recuperado em: 29 de outubro de 2011, de http://www.ead.fea.usp.br/semead/ 5semead/MKT/Delphi.pdf.

Schaltegger, S., Benett, M, \& Burritt, R. (2006). Eds.Sustainability, Accounting and Reporting. Dordrecht: Springer.

Veiga, J.E. da. (2005). Desenvolvimento sustentável: o desafio do século XXI. Rio de Janeiro: Garamond. 